\title{
Public oversight of the audit profession - Comparison of implemented practices in the EU and the U.S.
}

\author{
UDK: 33.025.13(4:73)(045)
}

\author{
Maja Zaman Groff \\ University of Ljubljana, Faculty of Economics, Slovenia \\ maja.zaman@ef.uni-lj.si
}

\author{
Marko Hočevar \\ University of Ljubljana, Faculty of Economics, Slovenia \\ marko.hocevar@ef.uni-lj.si
}

\begin{abstract}
Following financial scandals at the turn of the century, the audit profession in the European Union, the United States and elsewhere, has undergone profound legislative and regulatory reforms, including the requirement for intense public oversight of the profession. The article provides an overview of the development of external quality assurance systems in the audit profession in the EU and the U.S. with emphasis on the system of public oversight, implemented after the passing of the Sarbanes-Oxley Act of 2002 in the U.S. and the Statutory Audit Directive of 2006 in the EU. The aims of the article are: 1) to explain different backgrounds of external quality assurance systems in the EU and the U.S., 2) to describe implemented practices related to the public oversight system in the two regions and 3 ) to present the main findings of the existing empirical research focusing on the impact of the newly established systems of public oversight on the quality of audit services. Our literature research reveals that the evidence on the impact of the public oversight on the ultimate audit quality in the EU has not yet been provided because the Member States have only finished the implementation of the Statutory Audit Directive requirements into national legislations by the year 2008. In the U.S., on the other hand, first empirical evidence has been presented, suggesting that the quality of auditing has improved after the passing of the Sarbanes Oxley Act of 2002. So far evidence has been provided to support the proposition that PCAOB opinions are associated with earnings quality of the audit firm's clients, that auditors have become more conservative and that the new inspectors (as opposed to the former system of self-regulation) can hold the auditors to stricter standards by taking concrete actions against felonious auditors and imposing costly penalties.
\end{abstract}

Key words: audit profession, public oversight, quality assurance systems in EU and U.S., monitoring, peer review.

JEL: $M 48$

Uprava, letnik VII, 3/2009 
Maja Zaman Groff, Marko Hočevar

Public oversight of the audit profession - Comparison

of implemented practices in the EU and the U.S.

\section{Introduction}

Following the milestones of economic development, specialized areas of interest have developed within the accounting profession and a variety of accounting-related professions have emerged. Development of different accounting-related professions (e.g. financial and management accounting, tax consulting and auditing) followed the need for specialized services, sought by the state, public sector and business. Comparing different accounting-related professions it is crucial to emphasize that the majority, such as financial and management accounting, cost accounting and tax consulting have always been driven by private interest. In its early history, the auditing profession was no exception to this rule.

The period of the industrial revolution and high economic growth in Europe (the period between years 1750 and 1850) was the period of transformation of successful entrepreneurs and small family businesses into large industrial corporations. The period, following the industrial revolution and the separation of owners from the management, especially the second half of the 19th century, was the period of increasing role of auditors and the rise of the audit profession. At this time, auditors became important players in resolving the agency problem between diverse interests of owners (principals) and their appointed managers (agents). Auditors acted in the interest of owners to whom they periodically reported on the completed audits. Consequently, auditing contributed to improved quality of information flows and played important role in decreasing information asymmetry between principals and agents. As auditors were not only expected to detect clerical errors and omissions in financial statements, but also to report on any evidence of management fraud, they had to be independent of management.

With further development of financial markets the provision of an independent opinion on the financial statements to the general public became the primary objective of an audit and the auditors were recognized to act in public interest. The main audit objective gradually changed from the detection of fraud to reporting on the actual financial condition of an entity. Audited financial statements became crucial for functioning of capital markets because the auditing process reduced the information asymmetry between the management and diverse groups of players on capital markets. Several researchers have studied the relation between audit quality and its impact on financial state- 
ments credibility. Alles, Kogan and Vasarhelyi (2004, p. 184) claimed that assurance added value to communications between an auditee and its audience and that the degree to which audited financial statements added this value was directly related to the credibility of the auditor. Similarly, Teoh and Wong $(1993$, p. 365) provided evidence that companies increased the credibility of their financial statements by appointing high-quality auditors. Hillary and Lennox (2005, p. 216) suggested that an audit firm's average client preferred a high-quality auditing since high-quality auditing helps to reduce information risk and the cost of capital.

Today, among different accounting-related professions, only the audit profession is closely related to the public interest and is therefore most regulated. Consequently, the requests for and standards of external quality assurance systems for statutory audits have been included in national auditing regulations already before the profound changes in the profession-related regulation, represented by the Sarbanes-Oxley Act of 2002 (SOX) in the U.S. and the Directive 2006/43/EC (Statutory Audit Directive) in Europe.

Inclusion of quality assurance requests in national legislations of individual states was crucial because although audit reports did refer to the use of auditing standards and declared auditor's independence in the title of the report itself ("independent auditor's report"), there was no other assurance whether the audit was truly carried out in conformity with the standards declared in the report and whether the independence-related rules were respected, not to mention an essential question, what provisions the independence-related rules included. The need for external monitoring of audit profession originated from request for appropriate quality of audit services, including the auditor's independence.

External quality assurance system is the profession's principal means of demonstrating to the public, to regulators and other interested parties that auditors are performing at a level that meets the established auditing standards as well as ethical rules. In addition, it encourages the profession to implement quality improvements in auditing methods. Surveys, related to effects of quality assurance on quality of statutory audits (Recommendation on quality assurance for the statutory audits in the European Union, 2000) demonstrate that quality assurance is actually adding value in detecting and preventing weaknesses in the audit process and that it results in improvements of auditing procedures and internal quality control systems of audit firms. Taking into consideration that already in year 2000 statutory audits were mandatory in over 
Maja Zaman Groff, Marko Hočevar

Public oversight of the audit profession - Comparison

of implemented practices in the EU and the U.S.

three million limited liability and joint stock companies across the EU under the two accounting directives (at that time the 4th Directive on the Annual accounts of certain types of companies and the 7th Directive on Consolidated accounts of companies with limited liability), and that the 8th Directive at that time did not contain specific guidance related to audit function and external quality assurance, audit regimes and quality assurance systems differed significantly between different EU Member States as well as the U.S.

\section{Quality assurance for the statutory audit in the EU and the U.S. before the recent financial scandals}

Due to lack of any specific guidelines, a number of different external quality assurance systems have developed in practice. Depending on the status of persons in charge of carrying out the quality assurance, these can generally be classified as variations of two principal types of systems: monitoring and peer review (Public Oversight of the Accounting Profession in Europe, 2007, p.12):

- Monitoring refers to a situation where quality assurance reviews are undertaken by staff employed by an independent review organization (professional body or regulator).

- Peer review refers to a situation where the review organization organizes and supervises the reviews undertaken by experienced and authorized practitioners of audit firms or statutory auditors (hence the reference to "peer"), working on the contract basis.

Observing the divergent ways of external quality assurance development, the European Commission issued its first recommendations on quality assurance in November 2000 (Recommendation on quality assurance for the statutory audit in the European Union - Minimum requirements, 2000). The goal of these recommendations was to ensure that all statutory audits were covered by equivalent quality assurance systems with sufficient public oversight. The ultimate purpose of improved quality insurance in the audit profession was to improve the reliability and comparability of financial information and to 
restore confidence in the efficient functioning of the EU capital markets. The Recommendation on quality assurance for the statutory audit was passed as a result of the discussions within the EU Committee on Auditing, which is composed of representatives from the Member States and the European audit profession. The minimum requirements related to the implementation of quality assurance systems in the Member States still allowed certain flexibility: both basic methodologies (monitoring and peer review) were acknowledged when appropriate safeguards were applied. On the other hand, the ambition of the recommendation was to change the existing situation where not all EU statutory auditors were obliged to be covered by a quality assurance system (before the recommendation was passed some Member States did not have a system for quality assurance at all, whereas in other Member States coverage existed only voluntarily). The ultimate goal of the recommendation was to improve the quality of auditing services throughout the EU by encouraging quality assurance systems, which put forward specific requirements such as the frequency and the scope of the quality reviews and confidentiality. In particular, the requirements for public oversight composed of a majority of nonpractitioners, publication of the results and the possibility of access to the review files by the competent authorities were the major contributions of the recommendation to upgrade the existing quality assurance systems (Recommendation on quality assurance for the statutory audit in the European Union Minimum requirements, 2000).

In the U.S., the roots of the external quality assurance systems in the auditing profession can be traced to the early 1970's, when the profession became self-regulated following several accounting scandals that involved fraudulent financial reporting and caused the public to question audit effectiveness. After hearings at the U.S. Senate and House of Representatives, the SEC Practice Section (SECPS) was established by the American Institute of Certified Public Accountants (AICPA) and any AICPA member firm that was engaged in auditing financial statements of public companies was required to belong to the SECPS and was required to undergo a peer review at least once every three years (Lennox \& Pittman, 2009, p.3). On the other hand, audit firms with no public company clients were given an option to join voluntarily and these firms were also subject to peer reviews (Hilary \& Lennox, 2005, p.214). The primary focus of the peer review process was on the overall quality of the audit firm and the reviewers documented their findings in "peer review opinions" that were publicly available. In their reports, reviewers disclosed any systematic weakness found and issued an opinion that could be either "clean" (if 
Maja Zaman Groff, Marko Hočevar

Public oversight of the audit profession - Comparison of implemented practices in the EU and the U.S.

they found no significant weaknesses at the audit firm), "unmodified with weaknesses" (if weaknesses were significant but not serious), "modified" (if weaknesses were serious) or "adverse" (if weaknesses were very serious). Hilary and Lennox (2005) provided first evidence on the credibility of AICPA peer reviews. They carried out an extensive survey in which they studied whether the opinions issued by the peer reviewers provided credible information to clients about audit firm quality. They investigated the credibility of peer reviews by examining audit firm dismissals and appointments in the 12-month period following issuance of peer review opinions and found that the reviewed firms gained clients after receiving clean opinions and lost clients after receiving modified or adverse opinions. Their tests indicated that peer reviews were perceived informative about the quality of the audit firms. Casterella, Jensen and Knechel (2009, p.732) also found that there was a predictable link between the number of weaknesses identified in a firm's peer review report and the likelihood of that audit firm having a malpractice claim filed against it. Similarly, in their discussion of the changing role of audit committees in the corporate governance process, Woodlock and Claypool (2001) pointed out several dimensions that should be considered at the audit committee meetings to improve its oversight and the confidence in the company's financial statements. In the context of the external auditor selection they suggest the audit committee members to review a copy of the external auditor's latest peer review because "audit committees that review the peer review are in a better position to determine whether the external auditor is suited for auditing the company's records" (Woodlock and Claypool, 2001, p. 30).

The debate between advocates and opponents of the implemented quality assurance system through the self-regulation was strident and it was becoming increasingly a political one. Among the advocates of the system, Charles Kaiser, a former chair of the AICPA, stated that self-regulation provided credibility, generated public trust and reduced unnecessary and costly governmental intervention (Hilary \& Lennox, 2005, p. 214). On the other hand, peer review has come under considerable criticism from many members of the Congress, the media and others. The critics of self-regulation had argued that peer reviews lacked credibility (Hilary \& Lennox, 2005, p. 212) and the prevailing cynical view of these reviews by their opponents was consolidated in the following statement: "You scratch my back, I'll scratch yours" (Lennox \& Pittman, 2009, p. 3). This and other critiques were mainly related to the general lack of independence among reviewers and reviewees (Anantharaman, 2007, p. 8). The generally perceived lack of independence was primarily 
the consequence of possibility that the reviewee was allowed to choose the audit firm to carry out the peer review.

Following the financial scandals at the turn of the century, the audit profession has lost the confidence of all groups of players on financial markets. After long centuries of building the profession, it suddenly seemed to have reached the point of "dead end". Major players (governments, regulators, public agencies, investors and others) soon agreed that the profession that had been designated to act in the interest of public, has shifted its course to begin acting in the interest of profit. Unfortunately the consensus on the need for immediate action, in the sense of profound changes in the profession-related regulation, was reached too late to prevent the damage to financial markets and profession itself. The ambition to restore public confidence in audit profession, improve reliability of publicly available financial information and stabilize financial markets, led to profound legislative and regulatory reforms in the field of the audit profession in Europe, the U.S., and elsewhere. These reforms have redefined the roles of all players related to a public company's financial reporting process (management, internal and external auditors, boards of directors, supervisory boards and audit committees) and have highlighted the requirement for intense public oversight of the audit profession.

\section{Development of public oversight of the audit profession as the consequence of recent financial scandals}

The recent financial scandals, especially Enron and Worldcom, that caused the fall of one of the big players in the auditing services market, Arthur Andersen, have heavily undermined public confidence in the audit profession. Alles, Kogan and Vasarhelyi $(2004$, p. 188) point out that the prevailing theory behind corporate failure in the mind of the public was that "it is due to deliberate fraud between managers, aided and abetted by auditors, who, at best, are incompetent and, at worst, corrupt and outright compliant". Considering such prevailing view of the audit report users it was clear that significant modifications, regarding the oversight of the audit profession, were indispensable. Restoring auditor credibility was one of the major ambitions of both, the Sarbanes Oxley Act of 2002 in the U.S. and the Statutory Audit Directive (2006/43/EC) 
Maja Zaman Groff, Marko Hočevar

Public oversight of the audit profession - Comparison

of implemented practices in the EU and the U.S.

in the EU. This issue was given a priority due to the importance of audited financial statements in facilitating capital market transactions.

In the following two sections we present the characteristics of the newly implemented public oversight systems in the EU and the U.S. Because there is a high possibility that the new practices influence auditors' incentives, we are convinced that it is of major importance to study their impact on ultimate audit quality. DeFond (2009, p. 1) points out that while auditor incentives, most commonly associated with audit quality, are litigation and reputation concerns, oversight mechanisms that are used to monitor the profession are also likely to impact auditors' incentives. Therefore, at the end of each section, we attempt to provide any existing empirical evidence related to efficiency of the public oversight systems on the quality of audit services provided by audit firms.

\subsection{Public oversight of the audit profession in the EU}

In the EU, criteria for the quality assurance system were put forward in the Statutory Audit Directive in June 2006. With its principal scope to ensure consistently high quality of auditing services in all EU Member States, the Directive introduced a requirement for all statutory auditors and audit firms to be subject to a system of an independent quality assurance, organized independently from the reviewed statutory auditors and audit firms and subject to public oversight on the basis of home country control. The requirements of the Directive called for profound changes of quality assurance arrangements in a number of European countries.

Although the new requirements related to the audit profession entailed adjustments in national legislation of the Member States, the Directive still allows for considerable differences regarding how external quality assurance systems for statutory auditors and audit firms can be set up. In general, the two types of quality assurance systems that have been introduced already before the Statutory Audit Directive (monitoring and peer review), can be found in Europe. In monitoring, quality assurance reviews are undertaken by staff employed by a review organization. In peer review, the review organization organizes and supervises the reviews to be undertaken by experienced and authorized practitioners of audit firms or statutory auditors. Despite these differences, both systems of monitoring and peer review are considered to comply with the Statutory Audit Directive. Under either of the existing two systems, the newly established public oversight body may also attend the 
reviews as part of its oversight work. Several EU countries have selected the monitoring approach to exercise the oversight of the audit profession. Representatives of this group of countries are Great Britain, Ireland, Germany, Spain, Cyprus and Slovenia. On the other hand, the peer review approach was chosen by Italy, the Netherlands, Norway, Poland, Greece and Luxemburg. In practice, also a combined approach can be found. Such approach refers to a situation where oversight is primarily carried out by independent professionals, employed at professional institutes, in co-operation with auditors-practitioners working on a contractual basis. The primary advantage of this approach is that contractual partners have valuable experience in auditing and knowledge regarding business operation in specific business areas. The combined approach can be found in the Czech Republic, Denmark, Sweden, Austria and France (Quality assurance arrangements across Europe, 2006).

In the Directive not only types of selected quality assurance systems but also the system of their financing is subject to independent decision, taken by the Member State. Consequently, considerable differences regarding the public oversight financing exist among different EU countries. In table 1 we present the financing arrangements of the public oversight system in four selected EU countries and Switzerland.

Table 1 reveals that significant differences exist among European countries regarding financing of the public oversight systems across Europe. Taking into consideration the number of audit firms and the number of auditors, registered in different countries, it is still evident, that the total yearly available funds vary significantly among selected countries. Also, while the majority of countries have built the financing system of their public oversight on yearly fees, collected from auditors and audit firms, in some countries the public oversight system is financed exclusively from the state budget.

We believe that existing differences of established public oversight practices in different Member States raise a number of highly interesting questions. First, it can be assumed that the total amount of yearly available funds affects the quality of the work performed by the public oversight body. But the comparison of the funding systems and, particularly, the type of financing, also reveals that in countries with smallest amounts of yearly funds they are financed through the state budget and are therefore highly independent from auditors and audit firms. 
Maja Zaman Groff, Marko Hočevar

Public oversight of the audit profession - Comparison

of implemented practices in the EU and the U.S.

Table 1: Comparison of financing arrangements of the public oversight system in selected European countries

\begin{tabular}{|c|c|c|c|c|c|}
\hline & Finland & The Netherlands & Sweden & Switzerland & Slovenia \\
\hline $\begin{array}{l}\text { Number of } \\
\text { audit firms }\end{array}$ & 74 & 485 & 111 & 3067 & 52 \\
\hline $\begin{array}{l}\text { Number of } \\
\text { auditors }\end{array}$ & n.a. & 1438 & 4108 & 6545 & 208 \\
\hline $\begin{array}{l}\text { Public } \\
\text { oversight } \\
\text { body }\end{array}$ & $\begin{array}{l}\text { Auditing Board } \\
\text { of the Central } \\
\text { Chamber of } \\
\text { Commerce }\end{array}$ & $\begin{array}{l}\text { Authority for the } \\
\text { Financial Markets } \\
\text { (AFM) - Audit firm } \\
\text { supervision } \\
\text { department }\end{array}$ & $\begin{array}{l}\text { Supervisory } \\
\text { Board of } \\
\text { Public } \\
\text { Accountants }\end{array}$ & $\begin{array}{l}\text { Switzerland's } \\
\text { Federal Audit } \\
\text { Oversight } \\
\text { Authority }\end{array}$ & $\begin{array}{l}\text { Agency for } \\
\text { Public } \\
\text { Oversight of } \\
\text { the audit } \\
\text { profession }\end{array}$ \\
\hline $\begin{array}{l}\text { Type of } \\
\text { financing }\end{array}$ & $\begin{array}{l}\text { Yearly fees } \\
\text { from audit } \\
\text { firms }\end{array}$ & $\begin{array}{l}\text { Yearly fees from } \\
\text { audit firms }\end{array}$ & $\begin{array}{l}\text { Yearly fees } \\
\text { from auditors }\end{array}$ & $\begin{array}{l}\text { Yearly fees from } \\
\text { audit firms and } \\
\text { auditors }\end{array}$ & $\begin{array}{l}\text { Financed } \\
\text { exclusively } \\
\text { from budget } \\
\text { (180.000 } \\
\text { EUR) }\end{array}$ \\
\hline $\begin{array}{l}\text { Yearly } \\
\text { amount } \\
\text { of fees } \\
\text { collected }\end{array}$ & $\begin{array}{l}700.000 \text { EUR } \\
\text { (expected rise } \\
\text { to } 1 \text { mio EUR) }\end{array}$ & $\begin{array}{l}\text { Must be approved } \\
\text { by the Ministry of } \\
\text { Finance regarding } \\
\text { planned activities }\end{array}$ & 4,2 mio EUR & 4,2 mio EUR & 0 \\
\hline $\begin{array}{l}\text { Number of } \\
\text { employees }\end{array}$ & 9 & 20 & 20 & 22 & 5 \\
\hline
\end{tabular}

Source: Financing of public oversight bodies, 2009 (adopted)

As countries with higher budgets are mostly financed by the fees collected from auditors and/or audit firms, this raises the question of independence which is (in theory and practice) highly related with the audit quality. And second, no evidence has so far been provided on influence of the type of the quality assurance system selected (monitoring or peer review) on audit quality. It is important to point out that within both systems special attention should be paid to specific aspects of the quality assurance system. In the monitoring system it is crucial to maintain high experience levels and professional competencies for reviewers. In the peer review system the emphasis is focused on 
Maja Zaman Groff, Marko Hočevar

Public oversight of the audit profession - Comparison of implemented practices in the EU and the U.S.

compliance with the independence-related standards. An interesting question arising from the debate on the trade-off between expertise and independence and its influence on the quality of work performed by the oversight body has not yet been answered.

\subsection{Public oversight of the audit profession in the U.S.}

In the U.S., at the time of financial scandals, audit firms had been subject to self-regulation under peer review for nearly 25 years. The financial reporting failures renewed the on-going concerns about the effectiveness of selfregulation, the peer review program and the discussion whether monitoring separate from the profession is essential for ensuring high-quality auditing (Lennox, Pittman, 2009, p. 1). Empirical research, focusing on the period before the financial scandals, reveals mixed results regarding the efficiency of the existing quality assurance system. On one hand, survey results supported the high information value of peer reviews. The survey, carried out by Hilary and Lennox (2005) provided evidence that peer-review reports were associated with perceived audit quality. Their work was extended by Casterella, Jensen and Knechel (2009), who tested if peer review opinions were also associated with actual audit quality. Their research provides evidence that peer review opinions were associated with actual audit quality in the sense of predicting audit failure such as malpractice claims alleging auditor negligence, overworking staff and taking on risky clients (Casterella, Jensen \& Knechel, 2009, p. 732). On the other hand, an important factor, adding to the debate whether the self-regulation of the profession failed to protect investors against poor quality audits, was the fact that Deloitte and Touche gave Arthur Andersen a favorable opinion even after the Enron and other potential audit failures came to light. Moreover, despite many publicly known cases of audit failure, none of the major audit firms has ever received a negative peer review opinion (Alles, Kogan \& Vasarhelyi, 2004, p. 185). Casterella, Jensen and Knechel (2009, p. 714) indicate that the general observation (although at that time not yet systematically studied) was that most audit failures involved firms receiving clean (unmodified) peer-review reports. On basis of extent literature review they also point out the evidence that peer-reviews report relatively few weaknesses, that almost all peer-reviews result in unmodified reports, that most audit failures involve peer-reviewed firms and that peer-review cannot be effective because of the general lack of independence between reviewers and reviewees. 
Maja Zaman Groff, Marko Hočevar

Public oversight of the audit profession - Comparison

of implemented practices in the EU and the U.S.

The system of oversight of the audit profession was profoundly changed following the Sarbanes-Oxley Act of 2002, when the system of self-regulation through peer review process for the audit firms with SEC clients was replaced by independent inspections, carried out by the newly created body, the Public Company Accounting and Oversight Board (PCAOB). Under the new legislation, audit firms are required to undergo PCAOB inspection annually if they audit at least 100 public companies and triennially if they have less than 100 clients among public companies (Anantharaman, 2007, p. 10). On the other hand, audit firms with no SEC clients continue to be subject to peer reviews, administered by the AICPA. One of the consequences of the Sarbanes Oxley Act, regarding the establishment of the PCAOB was that 47 small audit firms ceased auditing public clients during the period immediately following the passage of SOX. The survey of the factors behind their decision revealed that concerns about the PCAOB inspections were the auditors' primary reasons for exiting the industry (DeFond, 2009).

\section{Empirical evidence on the impact of the newly established public oversight systems on quality of audit services}

In the U.S., an increasing number of researchers have been focusing their empirical research on comparison between the self-regulation of the audit profession and the new public oversight practices. Anantharaman (2007, p. 33) found that firms that themselves review other firms consistently receive more favorable opinions from peer reviewers than from PCAOB reviews and that firms with peer reviewers who are less likely to be independent (such as smaller, non-competing firms) and firms likely to be "peer review specialists" also receive significantly more favorable opinions from peer review than from the PCAOB. Gunny and Zhang (2006, p. 12) found that peer review opinions were not associated with earnings quality of the audit firm's clients whereas they found evidence to support the proposition that PCAOB opinions were associated with earnings quality of the audit firm's clients. They confirmed that audit firms that receive favorable PCAOB opinions have clients with higher earnings quality. Moreover, DeFond $(2009$, p.2) concludes that the new inspectors can hold the auditors to stricter standards by imposing costly penalties: 
Maja Zaman Groff, Marko Hočevar

Public oversight of the audit profession - Comparison of implemented practices in the EU and the U.S.

"...unlike the peer reviewers the PCAOB inspectors are able to take actions against felonious auditors which can result in large penalties. These actions can include notifying the SEC of auditor transgressions, notifying the Justice Department of possible criminal violations, and disciplinary proceedings by the PCAOB itself". Consequently, he argues that auditors might have incentives to improve audit quality in anticipation of the inspections. Some evidence suggesting that the quality of auditing and the quality of financial reporting have improved after the passing of the Sarbanes Oxley Act of 2002 has also been presented by Cohen, Dey and Lys (2008), confirming that earnings management has been declining and by Lobo and Zhou (2006) pointing out that after the passing of the SOX, auditors appear to be increasingly conservative.

In the EU, on the other hand, the Member States have only finished the implementation of the Statutory Audit Directive requirements into national legislations by the year 2008. In the U.S., at least 4 years have passed from the reform (2002) to the publication of first contributions in high quality accounting journals such as Accounting Horizons (Lobo and Zhou, 2006), The Accounting Review (Cohen, Dey and Lys, 2008) and Journal of Accounting and Economics (DeFond, 2009). In our opinion, the finding, that no empirical evidence has so far been provided on how the newly established systems of public oversight in various EU Member States influence the ultimate quality of audit services, can be mainly contributed to the fact that so far no comparable sets of data have been available to allow for a high quality statistical analysis.

\section{Conclusion}

Following the financial scandals at the turn of the century, the audit profession has lost the confidence of all groups of players on financial markets. The ambition to restore public confidence in audit profession, improve reliability of publicly available financial information and stabilize financial markets, led to profound legislative and regulatory reforms in the field of the audit profession in Europe, the U.S., and elsewhere. These reforms included the requirement for intense public oversight of the audit profession. Preliminary surveys, related to effects of quality assurance systems on quality of statutory audits demonstrated that quality assurance was actually adding value in detecting and preventing weaknesses in the audit process and that it 
Maja Zaman Groff, Marko Hočevar

Public oversight of the audit profession - Comparison

of implemented practices in the EU and the U.S.

resulted in improvements of auditing procedures and internal quality control systems of audit firms.

In the article we explained different backgrounds of external quality assurance systems in the EU and the U.S., described implemented practices related to the public oversight system in the two regions and presented the main findings of the existing empirical research focusing on the impact of the newly established systems of public oversight on the quality of audit services provided by audit firms.

Studying the consequences of implementation of the new public oversight is a matter of high importance for two reasons. First, this issue is related to a long-standing debate regarding the trade-off between expertise (represented by the oversight through monitoring and peer reviews by professional organizations) on one hand and independence (represented by the more objective public oversight of the profession) on the other. Second, it is crucial to know how the new quality assurance system affects the ultimate quality of the audit services provided and how it signals actual audit quality.

Our research of published contributions of various researchers, focusing their empirical studies on the impact of public oversight system on quality of audit services provided by audit firms reveals that the evidence for the EU has not yet been provided because the Member States have only finished the implementation of the Statutory Audit Directive requirements into national legislations by the year 2008. In the U.S., on the other hand, first empirical evidence has already been presented. Various researchers report empirical results in support of the proposition that the quality of auditing has improved after the passing of the Sarbanes Oxley Act of 2002. So far evidence has been provided to confirm that earnings management has been declining, that auditors have become more conservative and that the new PCAOB inspectors can hold the auditors to stricter standards by taking concrete actions against felonious auditors and by imposing costly penalties. 


\section{Maja Zaman Groff, Marko Hočevar \\ Public oversight of the audit profession - Comparison of implemented practices in the EU and the U.S.}

Maja Zaman Groff, PhD, is Assistant Professor and a member of the Accounting and Auditing Department at the University of Ljubljana, Faculty of Economics. Her areas of research interest include auditing-related issues such as the role of auditing and audit committees in corporate governance and quality assurance. She cooperates with a Slovene audit firm and is involved in the corporate governance of various Slovene corporations as a member of audit committees. She has published a number of professional and scientific papers.

Marko Hočevar, PhD, is Full Professor of Accounting and Auditing at the University of Ljubljana, Faculty of Economics. He has acquired various experience working with industry and public sector including: serving as an independent expert in many business and accounting cases, working with corporations and public organizations in designing costing systems, developing and implementing planning and control systems. He has written several textbooks and professional books and has published a number of professional and scientific papers.

\section{References}

- $\quad 4$ th Directive on the Annual accounts of certain types of companies (78/660/EEC). Retrieved 1. 9. 2009, from http://eur-lex.europa.eu/LexUriServ/LexUriServ.do?uri= CELEX:31978L0660: EN:HTML

- $\quad$ 7th Directive on Consolidated accounts of companies with limited liability (83/349/EEC). Retrieved 1. 9. 2009, from http://europa.eu/scadplus/leg/en/lvb/l26010.htm

- $\quad$ Alles, M. G., Kogan, A. \& Vasarhelyi, M. A. (2004). Restoring auditor credibility: tertiary monitoring and logging of continuous assurance systems. International Journal of Accounting Information Systems, 5, 183-202.

- Anantharaman, D. (2007). How objective is peer review: Evidence from self-regulation of the accounting profession. Working paper. New York: Columbia University.

- Casterella, J. R., Jensen, K. L. \& Knechel, W. R. (2009). Is self-regulated peer review effective at signaling audit quality? The Accounting Review, 84(3), 713-735.

- Cohen, D. A., Dey, A. \& Lys, T. (2008). Real and accrual-based earnings management in the pre- and post- Sarbanes Oxley periods. The Accounting Review 83(3), 757-787. 
Maja Zaman Groff, Marko Hočevar

Public oversight of the audit profession - Comparison

of implemented practices in the EU and the U.S.

- DeFond, M. L. (2009). How should the auditors be audited? Comparing the PCAOB inspections with the AICPA peer reviews. Journal of Accounting and Economics, article in press, doi:10.1016/j.jacceco.2009.04.003.

- Directive 2006/43/EC of the European Parliament and of the Council. Retrieved 1. 9 2009, from http://eur-lex.europa.eu/LexUriServ/LexUriServ.do?uri=OJ:L:2006: 157:0087:0107:EN: PDF

- Financing of public oversight bodies (2009). Agency for public oversight of the audit profession.

- Gunny, K. \& Zhang, T. (2006). The association between earnings quality and regulatory report opinions in the accounting industry: AICPA peer review and PCAOB inspections. Working paper.

- Hilary, G. \& Lennox, C. (2005). The credibility of self-regulation: Evidence from the accounting profession's peer review program. Journal of Accounting and Economics, 40, 211-229.

- Lennox, C. \& Pittman, J. (2009). Auditing the auditors: Evidence on the recent reforms to the external monitoring of audit firms. Journal of Accounting and Economics, article in press, doi: 10.1016/j.jjacceco.2009.04.002.

- Lobo, G. \& Zhou, J. (2006). Did conservatism in financial reporting increase after the Sarbanes Oxley Act? Initial evidence. Accounting Horizons, 20(1), 57-73.

- Public oversight of the accounting profession in Europe (2007). Accountancy Ireland, 39(2), 12.

- Quality assurance arrangements across Europe (2006). Brussels: Fédération des Experts Comptables Européens.

- Quality Assurance for Statutory Audit (2008). Fact sheet, September 22, 2008. Brussels: Fédération des Experts Comptables Européens.

- Recommendation on quality assurance for the statutory audit in the European Union Minimum quality assurance standards (2000). Retrieved 10. 9. 2009, from http://ec.europa.eu/internal_market/smn/smn24/s24mn23.htm

- $\quad$ Sarbanes - Oxley Act of 2002. Retrieved 10. 9. 2009, from http://www.sarbanesoxley.com/section.php?level=2\&pub_id=Sarbanes-Oxley\&chap_id=PCAOB1

- $\quad$ Teoh, S. \& Wong, T. J. (1993). Perceived auditor quality and the earnings response coefficient. The Accounting Review, 68 (2), 346-366.

- Woodlock, P. \& Claypool, G. (2001). Your audit committee: How to cope with the end of the "rubber stamp" era. The Journal of Corporate Accounting \& Finance, 12(4), 27-39. 


\section{POVZETEK}

\section{JAVNI NADZOR NAD REVIDIRANJEM - PRIMERJAVA SISTEMOV, UVEDENIH V EVROPSKI UNIJI IN V ZDRUŽENIH DRŽAVAH AMERIKE}

Vzporedno z glavnimi mejniki $v$ zgodovini gospodarskega razvoja so se $v$ okviru računovodske stroke razvijala specializirana področja, na katerih se je oblikovalo več $z$ računovodstvom povezanih poklicev. Razvoj takšnih poklicev (npr. finančni računovodja, davčni svetovalec, revizor) je sledil potrebam po specializiranih računovodskih storitvah, po katerih sta povpraševala tako javni kot tudi gospodarski sektor. Ob primerjavi različnih, z računovodstvom povezanih dejavnosti, je pomembno poudariti, da večino teh, kot so na primer finančno (pa tudi stroškovno ali poslovodno) računovodstvo in davčno svetovanje, že od samega začetka usmerja zasebni interes. $V$ svoji zgodnji zgodovini je to pravilo veljalo tudi za poklic revizorja. Danes je med vsemi računovodskimi poklici le poklic revizorja tesno povezan z javnim interesom in je zato med vsemi poklici tudi najbolj zakonsko reguliran in nadziran. Glede na to, da se nadzor nad kakovostjo izvajanja računovodskih poklicev, ki jih usmerja zasebni interes, izvaja na trgu prek ponudbe in povpraševanja, je treba nadzor nad kakovostjo opravljanja revizijske dejavnosti zakonsko regulirati, da bi zagotovili in ohranili delovanje $v$ javnem interesu.

Vključitev zahtev po vzpostavitvi primernega sistema obvladovanja kakovosti revizijskega dela $v$ zakonodajo je izredno pomembna za uresničevanje javnega interesa na področju revidiranja. Čeprav so se revizorji $\checkmark$ revizijskih poročilih že pred vključitvijo teh zahtev $v$ zakonodajo sklicevali na uporabo revizijskih standardov in izrecno izjavljali svojo neodvisnost že $v$ samem naslovu revizorjevega poročila ("poročilo neodvisnega revizorja«), dejanskega zagotovila, da so bili revizijski standardi pri izvedbi revizije resnično upoštevani in so bila upoštevana vsa pravila, povezana z neodvisnostjo revizorja, ni bilo. Potreba po zunanjem nadzoru nad revidiranjem tako izhaja iz zahteve po ustrezni kakovosti revizijskih storitev, vključno z zagotavljanjem revizorjeve neodvisnosti.

Primerno zasnovan in dosledno izvajan sistem zunanjega obvladovanja kakovosti revizijskih storitev je najbolj učinkovit način, s katerim revizor svojim strankam, državi in javnosti dokazuje, da izvaja revizijske storitve 
Maja Zaman Groff, Marko Hočevar

Public oversight of the audit profession - Comparison

of implemented practices in the EU and the U.S.

v skladu z zahtevami revizijskih standardov in etičnih načel. Poleg tega takšen sistem spodbuja uvajanje izboljšav $v$ revizijske postopke. Raziskave, ki se osredotočajo na proučevanje učinkov zunanjega obvladovanja kakovosti zakonskih revizij v Evropski uniji, kažejo, da ustrezno zasnovani in izvajani sistemi dejansko pripomorejo k odkrivanju in preprečevanju pomanjkljivosti $v$ procesu revidiranja in se zrcalijo $v$ večji kakovosti opravljenih revizijskih storitev (Recommendation on quality assurance for the statutory audits in the European Union, 2000). Upoštevaje podatek, da je bilo v Evropski uniji že $v$ letu 2000 kar tri milijone družb z omejeno odgovornostjo in delniških družb zavezanih $k$ obvezni reviziji letnih računovodskih izkazov $v$ skladu $z$ računovodskima direktivama (s tedanjima četrto direktivo o letnih računovodskih izkazih posameznih vrst družb in sedmo direktivo o konsolidiranih računovodskih izkazih) in da osma (revizijska) direktiva $v$ tem času še ni vsebovala posebnih navodil v zvezi s sistemom obvladovanja kakovosti revizijskih storitev, so se $v$ posameznih državah oblikovali zelo različni sistemi obvladovanja kakovosti revizijskega dela.

Nedavni finančni škandali, predvsem Enron in Worldcom (ki sta povzročila padec enega izmed največjih akterjev na trgu revizijskih storitev, revizijske družbe Arthur Andersen), so močno zamajali zaupanje javnosti v revizijsko stroko. Alles, Kogan in Vasarhelyi (2004, str. 188) navajajo, da je bilo prevladujoče javno mnenje po izbruhu finančnih škandalov, da gre za "...posledice namernih poslovodskih prevar ob pomoči revizorjev, ki so $\mathrm{v}$ najboljšem primeru nesposobni, v najslabšem primeru pa podkupljeni«. Upoštevaje takšen prevladujoč pogled na kakovost revizijskih storitev $v$ očeh uporabnikov revizijskih poročil, so bile obsežne spremembe, povezane z nadzorom revizijske dejavnosti, nujne. Ponovna vzpostavitev zaupanja $v$ revizijsko stroko, povečanje verodostojnosti javno dostopnih računovodskih poročil ter stabiliziranje finančnih trgov so bili glavni cilji zaostrene zakonodaje, tako Sarbanes - Oxleyevega zakona iz leta $2002 \mathrm{v}$ ZDA kot tudi Direktive 2006/43/ES o obveznih revizijah letnih in konsolidiranih računovodskih izkazov družb iz leta 2006 v Evropski uniji.

Članek opisuje različne poti razvoja sistemov obvladovanja kakovosti revidiranja v Evropski uniji in v Združenih državah Amerike ter sisteme, ki so bili $\vee$ EU in $\vee$ ZDA uvedeni za potrebe izvajanja javnega nadzora nad dejavnostjo revidiranja. Predstavljene so tudi glavne ugotovitve nekaterih empiričnih raziskav, ki se osredotočajo na proučevanje vpliva novih 


\section{Maja Zaman Groff, Marko Hočevar \\ Public oversight of the audit profession - Comparison of implemented practices in the EU and the U.S.}

mehanizmov javnega nadzora nad revidiranjem revizijskih storitev, ki jih izvajajo revizijske družbe.

Poznavanje posledic uvedbe novih sistemov javnega nadzora nad revidiranjem je ključnega pomena iz dveh razlogov. Prvič, ker je to področje povezano z zelo aktualno razpravo o prednostih in slabostih različnih vrst nadzora, ki so na eni strani povezane $z$ visoko ravnjo strokovnega znanja (običajno se visoka strokovnost pripisuje sistemu medsebojnega nadzora oz. sistemu "peer review (1), na drugi strani pa z visoko ravnjo neodvisnosti (le-ta je $v$ največji meri zagotovljena z neodvisnim nadzorom oz. s sistemom "monitoring"). In drugič, ker je pomembno spremljati, kako novo uvedeni sistemi obvladovanja kakovosti vplivajo na kakovost revizijskih storitev in kakšne signale o dejanski kakovosti takšen sistem pošilja uporabnikom revizijskih poročil.

$\checkmark$ Združenih državah Amerike vse več raziskovalcev proučuje razlike med novo uvedenim sistemom javnega nadzora (ki ga $v$ ZDA izvaja Odbor za javni nadzor oz. Public Company Accounting and Oversight Board PCAOB) in nekdanjo samoregulacijo revizijske dejavnosti, ki se je izvajala prek sistema medsebojnega nadzora ("peer review»).

Anantharaman (2007, str. 33) na primer ugotavlja, da revizijske družbe, ki se tudi same ukvarjajo z izvajanjem medsebojnega nadzora, redno prejemajo boljša poročila o kakovosti od izvajalcev nadzora $v$ sistemu medsebojnega nadzora kot od PCAOB. Na podlagi izsledkov raziskave avtor ugotavlja tudi, da revizijske družbe, ki izvajajo medsebojne preglede in za katere je manj verjetno, da dosledno ustrezajo kriterijem neodvisnosti (gre predvsem za manjše revizijske družbe) in tudi revizijske družbe, ki so se $v$ večji meri specializirale za izvajanje medsebojnih pregledov, prav tako pridobivajo bistveno bolj ugodna mnenja iz medsebojnih pregledov kot od PCAOB.

Gunny in Zhang (2006, str. 12) poročata, da mnenja, ki izhajajo iz medsebojnih pregledov, niso povezana s kakovostjo izkazanega poslovnega izida (»earnings quality") pri naročnikih revizijskih storitev revizijske družbe. Potrdila pa sta hipotezo, da je kakovost izkazanega poslovnega izida pri strankah revizijske družbe povezana z mnenjem, ki ga izda PCAOB kot organ javnega nadzora. Avtorja tako ugotavljata, da imajo revizijske družbe, ki prejemajo pozitivna mnenja PCAOB, stranke z višjo kakovostjo izkazanih poslovnih izidov.

DeFond (2009, str. 2) ugotavlja, da imajo novi inšpektorji kot izvajalci javnega nadzora $v$ primerjavi $z$ nekdanjim sistemom samoregulacije $v$ 
Maja Zaman Groff, Marko Hočevar

Public oversight of the audit profession - Comparison

of implemented practices in the EU and the U.S.

rokah učinkovitejše mehanizme, na podlagi katerih lahko uveljavljajo strožje standarde kakovosti, in sicer pravi, da "... za razliko od izvajalcev medsebojnega nadzora lahko inšpektorji PCAOB $v$ primeru nekaterih pomembnejših odkritih nepravilnostih sprožijo ukrepe, katerih posledice so visoke kazni za revizijske družbe. Ti ukrepi vključujejo prijavljanje nepravilnosti organu, zadolženemu za nadzor borz in vrednostnic (Securities and Exchange Commission - SEC), posredovanje izsledkov o morebitnih ugotovljenih kriminalnih dejanjih Ministrstvu za pravosodje in disciplinske ukrepe, ki jih izvaja neposredno PCAOB«. Avtor meni, da so zato revizijske družbe že v fazi pričakovanja javnega nadzora motivirane $k$ izboljševanju kakovosti revizijskih storitev.

Nekatere dodatne dokaze, ki kažejo, da se je po uvedbi Sarbanes Oxleyevega zakona kakovost revizijskih storitev, z njo pa tudi kakovost računovodskih poročil družb, $v$ katerih se izvaja revidiranje računovodskih izkazov, izboljšala, podajajo tudi Cohen, Dey in Lys (2008). Avtorji potrjujejo, da so po uvedbi zakona vse manj zaznani primeri prilagajanja poslovnega izida pri naročnikih revizijskih storitev. Lobo in Zhou (2006) pa dodajata, da so po uvedbi zakona revizorji postali bolj konservativni.

Medtem, ko je bilo v Združenih državah Amerike objavljenih že nekaj raziskav $s$ tega področja, pa rezultatov tovrstnih raziskav $v$ Evropski uniji še ni. Državam članicam EU je bila namreč ob uvedbi Direktive 2006/43/ES o obveznih revizijah letnih in konsolidiranih računovodskih izkazov družb dana možnost, da zahteve direktive vključijo $v$ svoje nacionalne zakonodaje $v$ roku dveh let, to je do sredine leta 2008. $V$ ZDA so minila vsaj štiri leta od uvedbe Sarbanes - Oxleyevega zakona leta 2002 do objave prvih izsledkov raziskav $v$ prvorazrednih revijah $s$ področja računovodstva in revizije, kot so npr. Accounting Horizons (Lobo and Zhou, 2006), The Accounting Review (Cohen, Dey and Lys, 2008) in Journal of Accounting and Economics (DeFond, 2009). Avtorja menita, da gre razloge za zaostanek na področju proučevanja posledic uvedbe novih sistemov javnega nadzora nad revidiranjem na kakovostjo revizijskih storitev $v$ Evropski uniji pripisati predvsem dejstvu, da doslej še ni bilo na voljo kakovostnih primerljivih podatkov, ki bi lahko služili kot osnova za izvedbo kakovostne statistične analize. 